
April 1942

\title{
SOME PROPERTIES OF THE DRY AIR-SETTING TYPE OF REFRACTORY BONDING MORTAR
}

\author{
By Raymond A. Heindl and William L. Pendergast
}

\begin{abstract}
Seventeen brands of air-setting refractory mortars of the type marketed in the dry condition were investigated in the unheated state with regard to tempering water, fineness of grain, soluble alkali content, pyrometric-cone equivalent, suitability for troweling and dipping, drying and setting properties, and strength. After heat treatments at various final temperatures the strengths of the mortars were determined. In rupturing assemblages of two half-brick and mortar, the types of failure were noted. The tendency of the mortars to shrink, crack, and flow when exposed to high temperatures, both in fusion blocks and in units of three brick each, was also investigated.

The ingredients of the mortars were all fine-grained, only a small amount being retained on a No. 40 sieve. The strengths of the neat mortars covered a wide range; the strengths of those received and stored in metal drums indicated the desirability of storage in airtight containers. In a series of heat treatments the neat mortars in general were found to have the least strength when preheated at $750^{\circ} \mathrm{C}$. However, the least strengths of the majority were noted in assemblages of brick and mortar preheated at $1,000^{\circ} \mathrm{C}$. The mechanical troweling machine gave a better indication of the workability of the mortars than did the time-of-set test. Observations made on the mortars heated in fusion blocks in general corroborated the shrinkage, cracking, and fusion of the same mortars heated in brick piers.
\end{abstract}

\section{CONTENTS}

I. Introduction Page

II. Materials and containers

III. Preparation of specimens and methods of testing _. _ _ _ _ _ _ 402

1. Mortar

(a) Mixing and mixing water $\ldots \ldots \ldots \ldots 2$

(b) Sieve analysis....

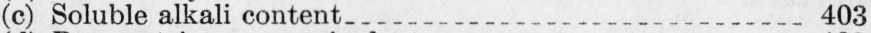

(d) Pyrometric-cone equivalent_... . . . . . . . . . . . 403

(e) Fusion-block test . . . . . . . . 403

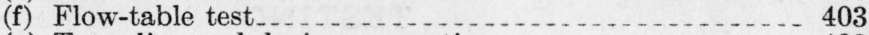

(g) Troweling and drying properties_.................... 403

(1) Appearance before drying . . . . . . . . . . . . . . 403

(2) Appearance after drying .................... 404

(h) Dipping ........................................ 404

(i) Transverse strength and linear shrinkage ........... 404

2. Assemblage of two half-brick and mortar. ........................ 404

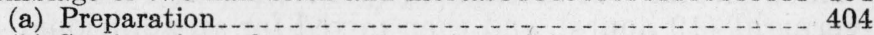

(b) Setting time of mortar

3. Pier of three brick and mortar

IV. Results and discussion

1. Mortar

(a) Mixing water $\ldots \ldots \ldots \ldots$

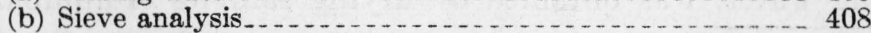

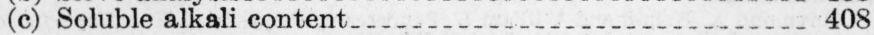


IV. Results and discussion-Continued.

Mortar-Continued.

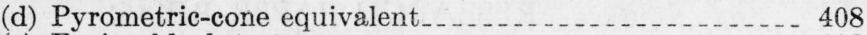

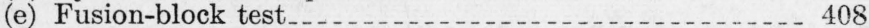

(f) Flow-table test_.......... 408

(g) Troweling .......... 408

(1) Appearance before drying . . . . . . 408

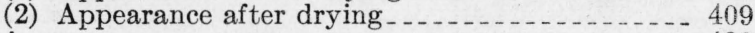

(h) Dipping _

(i) Transverse strength and linear shrinkage _........ 409

2. Assemblage of two half-brick and mortar. ............... 412

(a) Setting time of mortar, or water-retention test_....... 412

(b) Transverse strength

(c) Types of failure

(d) Relation of water content to setting time and to flow . . . 413

(e) Effect of atmosphere during heating on strength ...... 413

3. Pier of three brick and mortar.

V. Summary and conclusions

\section{INTRODUCTION}

Air-setting refractory mortars may be purchased either in the wet condition, ready for use, or dry, requiring only the addition of water. A report ${ }^{1}$ giving the results of a study of the wet type has been published. The results of a somewhat similar investigation of the dry type are herein reported.

Preliminary to the latter study, it was deemed advisable to determine suitable soaking and mixing periods for the average mortar after adding the water required for bringing it to the necessary consistency for use. The results of this preliminary investigation have also been reported. ${ }^{2}$

The information made available in the present report will be used as a basis for Federal specifications governing this commodity.

\section{MATERIALS AND CONTAINERS}

Seventeen air-setting mortars of the type marketed in the dry condition, 4 of which had a chromite base, were furnished by 12 manufacturers. As indicated in table 1, 6 of these mortars were received in sealed sheetiron drums and 11 in paper-lined burlap or jute sacks. The length of time of storage after receipt is reported, since storage in nonairtight containers causes deterioration in the strength of such mortars.

\section{PREPARATION OF SPECIMENS AND METHODS OF TESTING}

\section{MORTAR}

\section{(a) MIXING AND MIXING WATER}

Each mortar was mechanically mixed with water for 1 hour, soaked overnight (19 hours), and then mixed for an additional 4 hours before it was tested. The consistencies for troweling and for dipping were judged by "feel."

The loss in weight, assumed to indicate the water content or mixing water, was obtained by drying samples of approximately $200 \mathrm{~g}$

${ }_{1}$ Raymond A. Heindl and William L. Pendergast, Properties of air-setting refractory bonding mortars of the wet type, J. Research NBS 23, 7 (1940) RP1219.

2 Raymond A. Heindl and W. L. Pendergast, Effect of water content and mixing time on properties of air-setting refractory mortars containing sodium silicate, Bul. Am. Ceram. Soc. 19, 430 (1940). 
to a constant weight at about $105^{\circ} \mathrm{C}$. In most cases the drying time required was 96 hours.

\section{(b) SIEVE ANALYSIS}

The sieve analysis was made by the wet method ${ }^{3}$ on a sample of about $100 \mathrm{~g}$. Two tests were made-the first after slaking the mortar for 1 hour, and the second after machine-mixing 1 hour, soaking 19 hours, and machine-mixing 4 additional hours. The dried residue was sieved, using United States Standard Sieves Nos. 20, 40, 60, 100, and 200 , mechanically vibrated.

\section{(c) SOLUBLE ALKALI CONTENT}

The soluble alkali content of each mortar was determined on an unfired sample, weighing approximately $20 \mathrm{~g}$, taken from the bar specimens. The dried sample was digested with $200 \mathrm{ml}$ of water on a steam bath overnight, filtered, and the residue leached a second time overnight with the same quantity of water. The alkali content of the combined filtrates was determined by titration with $0.2 \mathrm{~N}$ hydrochloric acid, using methyl red as the indicator.

\section{(d) PYROMETRIC-CONE EQUIVALENT}

The pyrometric-cone equivalents (softening points) were determined according to the ASTM standard method, serial designation C 24-35. ${ }^{4}$ Cones were made from the mortars both before and after calcining at approximately $1,200^{\circ} \mathrm{C}$. In both cases, after placing the cones in plaques, they were heated to about $1,200^{\circ} \mathrm{C}$ and cooled before testing.

\section{(e) FUSION-BLOCK TEST}

The pyrometric-cone equivalent of the fusion block was 32 . Two blocks were used for each mortar, the compartments for holding the test materials being approximately $1 / 2$ in. and $1 / 8$ in. deep, respectively. Samples of the mortars sufficiently large to fill the compartments were taken from the machine-mixed batches prepared for other tests. The blocks containing the mortar samples were heated at $110^{\circ}, 750^{\circ}$, $1,000^{\circ}, 1,350^{\circ}$, and $1,500^{\circ} \mathrm{C}$. After cooling the mortars they were examined for shrinkage, bubbles, glassiness, and flow.

\section{(f) FLOW-TABLE TEST}

The flow-table test is described in Federal Specification SS-C-158 ${ }^{5}$ and also in the ASTM Standard for Masonry Cement, serial designation $\mathrm{C}$ 91-40. ${ }^{6}$

(g) TROWELING AND DRYING PROPERTIES

The troweling tests were made with the machine described by Heindl and Pendergast. ${ }^{7}$ A $1 / 4$-in. layer of mortar was spread evenly by hand-troweling on the upper 9 - by $4 \frac{1}{2}$-in. face of a brick by means of a template. Using such specimens, four tests of troweling properties were made by reducing this $1 / 4$-in. layer to $1 / 8$ in. in 1 stroke, to $1 / 16$ in. in 1 stroke, to $1 / 8$ in. in 25 strokes (0.005 in. per stroke), and to $1 / 16$ in. in 37 strokes.

(1) Appearance before drying. - The mortar caps were examined for uniformity of thickness and adherence to the brick, which are indications of satisfactory troweling properties.

\footnotetext{
${ }^{3}$ In general the test was similar to that described in Method C 92-36, p. 195, Am. Soc. Testing Materials, Standards, pt. 2, Non-Metals (1939).

Am. Soc. Testing Materials, Standards, pt. 2, Non-Metals, p. 214 (1939).

8 Cements, hydraulic; General Specification.

B Am. Soc. Testing Materials, Standards, Supplement, pt. 2, p. 1-7 (1940).

7 J. Research NBS 23, 7 (1940) RP1219.
} 
(2) Appearance after drying.-The mortared specimens were dried at room temperature and ordinary atmospheric conditions, and the mortar caps inspected for cracks, curling, and separation from the brick.

(h) DIPPING

A joint of mortar approximately $1 / 16$ in. thick, obtained by dipping the brick in a slurry, is frequently recommended by the manufacturers when mortars of this type are used for laying brick. Hence, testing the adaptability of the various mortars for conversion to the dipping condition was important. This was accomplished by placing a quantity of the mortar, which was in a troweling condition, in a pan and mixing it by hand with measured amounts of water until the desired consistency was obtained.

\section{(i) TRANSVERSE STRENGTH AND LINEAR SHRINKAGE}

The transverse strength (modulus of rupture) was determined on mortar bars 6 by 1 by $1 / 4$ in. over a 5 -in. span. The bars were formed by placing the mortar in brass molds under which were slips of newspaper resting on glass plates. The mold and bar were then removed from the glass and, with the attached paper down, placed on a firebrick. An initial set occurred within a few minutes, and the mold was then removed from the mortar bar with the aid of a safety razor blade. To prevent warping, the following drying schedule was used. The mortar bars were stored (1) in a constant-humidity room maintained for 48 hours at 60 - to 65 -percent humidity and $20^{\circ}$ to $22^{\circ} \mathrm{C}$, (2) 18 hours (overnight) at ordinary laboratory temperature and humidity, and (3) 27 hours in a drying oven at $105^{\circ}$ to $110^{\circ} \mathrm{C}$. The paper was removed from the mortar bars in the constant-humidity room when they had become sufficiently hard to permit handling without breakage. Hereafter the "positions" of the mortar bars will be designated as "original" (the side next to the paper being down) and "inverted" (the side next to the paper being up). In making the transverse-strength tests, half of the 10 mortar bars were tested in the "original" position in the cross-breaking machine and the other half in the "inverted" position.

\section{ASSEMBLAGE OF TWO HALF-BRICK AND MORTAR}

\section{(a) PREPARATION}

The standard 9-in. dry-pressed brick used in the test specimens for determining the strength of brick-to-mortar bond had a moderately coarse texture, an absorption of 8.6 percent, and a transverse strength of $590 \mathrm{lb} / \mathrm{in}^{2}$. By means of an abrasive wheel the brick were cut, parallel to the $2 \frac{1}{2}$ - by $4 \frac{1}{2}$-in. faces, into two equal parts. A laboratory screwpress ${ }^{8}$ was employed in the operation of bonding the two halfbrick with mortar. The press had an attached jig, or alining guide, to prevent lateral motion of the two halves of the brick when forced together with mortar between them. Uniform thickness of mortar joints, $1 / 16$ and $1 / 4$ in., for testing bonding strength and "time of set", respectively, was obtained by using properly sized spacers. The operation of bonding was as follows. After rigidly clamping the halves of brick against the jig, the end-molded faces and spacer were brought in contact by lowering the upper half-brick. This position, indicated by a scale attached to the frame of the machine, being

8 J. Research NBS 23, 7 (1940) RP1219. 
noted, the upper half of the brick was raised, the spacer removed, and approximately double the amount of mortar required for the joint was placed between the two half-brick. The upper portion was again lowered until it occupied the same position as when the spacers were used. The excess mortar was removed and the specimen taken from the press and subjected to the drying treatment described in the preparation of the mortar bars. These brick-and-mortar assemblages were heated simultaneously with the mortar bars made from the corresponding mortar. The modulus of rupture of the mortar joint was determined over an 8-in. span.

\section{(b) SETTING TIME OF MORTAR}

The time elapsing between placing the mortar on the brick and the attainment of sufficient mortar stiffness to prevent flow under a constant load of $50 \mathrm{lb}$. was designated "time of set." When removed from the press, the assemblage (1/4-in. mortar joint) in its original vertical position stood for 3 minutes from the time the mortar was first placed on the brick before being gently loaded with a 50-lb. weight. It was noted whether such loading caused mortar to be squeezed from the joint. If no flow occurred, additional tests with newly prepared assemblages were made and the original time of 3 minutes was reduced to 2 minutes. If, however, flow was observed, then the original time was increased by 3 -minute increments until the mortar was set and no flow occurred. The final time was then reduced by one or two 1-minute decrements until the mortar was again squeezed from the joint.

\section{PIER OF THREE BRICK AND MORTAR}

A second type of brick-and-mortar assemblage was made which consisted of a pier of two standard-size brick and two half-brick laid flat to give one vertical and two horizontal joints. Three of these piers were laid up with a 1/16-in. dipped joint and three with a 1/8-in. troweled joint, spacers being used to obtain the desired joint thickness.

The piers were examined for defects of the mortar and mortar joint after curing and drying and after heating them at $750^{\circ} \mathrm{C}$ for 24 hours, at $1,350^{\circ} \mathrm{C}$ for 1 hour, and at $1,500^{\circ} \mathrm{C}$ for 1 hour.

\section{RESULTS AND DISCUSSION}

\section{MORTAR}

(a) MIXING WATER

The amounts of water, in percentages of the dry weight of the mortar, used for bringing the mixtures to the proper consistencies for making test bars, troweling, and dipping, respectively, are given in table 1 , columns 11,15 , and 20 .

The percentages of water ranged from 12.8 to 36.9 in the bars, 16.6 to 43.0 in the mortars of troweling consistency, and 20.7 to 60.1 in those of dipping consistency.

In opposition to the general trend, there were two cases in which the water content used for troweling was less than that in the bars and five cases in which approximately the same content of water was used for both purposes.

Without exception the water content of the mortar adjusted to a dipping consistency was greater than that of troweling consistency. 
TABLE 1.-Some properties of air-setting refractory

\begin{tabular}{|c|c|c|c|c|c|c|c|c|c|c|}
\hline \multirow[b]{2}{*}{$\begin{array}{l}\text { Mor- } \\
\text { tar }\end{array}$} & \multirow[b]{2}{*}{ Container 1} & \multirow[b]{2}{*}{$\begin{array}{l}\text { Stored } \\
\text { before } \\
\text { testing }\end{array}$} & \multicolumn{4}{|c|}{ Sieve analysis } & \multirow[b]{2}{*}{$\begin{array}{l}\text { Alkali } \\
\text { as } \\
\mathrm{Na}_{2} \mathrm{O}\end{array}$} & \multicolumn{2}{|c|}{$\begin{array}{l}\text { Pyrometric-cone } \\
\text { equivalent }\end{array}$} & \multirow[b]{2}{*}{$\begin{array}{l}\text { Water } \\
\text { con- } \\
\text { tent } \\
\text { of neat } \\
\text { mortar } \\
\text { used in } \\
\text { bar } \\
\text { speci- } \\
\text { mens }\end{array}$} \\
\hline & & & $\begin{array}{c}\text { Re- } \\
\text { tained } \\
\text { on No. } \\
40\end{array}$ & $\begin{array}{c}\text { Passed } \\
\text { No. 40; } \\
\text { re- } \\
\text { tained } \\
\text { on No. } \\
60\end{array}$ & $\begin{array}{c}\text { Passed } \\
\text { No. 60; } \\
\text { re- } \\
\text { tained } \\
\text { on No. } \\
100\end{array}$ & $\begin{array}{c}\text { Passed } \\
\text { No. 100, } \\
\text { re- } \\
\text { tained } \\
\text { on No. } \\
200\end{array}$ & & Raw & Calcined & \\
\hline (1) & (2) & (3) & (4) & (5) & (6) & (7) & (8) & (9) & (10) & (11) \\
\hline$A-3$ & Bag & $\begin{array}{r}\text { Months } \\
1\end{array}$ & $\begin{array}{l}\text { Percent } \\
0.6 \\
3.2\end{array}$ & $\begin{array}{r}\text { Percent } \\
5.4 \\
6.5\end{array}$ & $\begin{array}{r}\text { Percent } \\
15.6 \\
17.1\end{array}$ & $\begin{array}{r}\text { Percent } \\
23.3 \\
25.5\end{array}$ & $\begin{array}{l}\text { Percent } \\
\} \quad 0.57\end{array}$ & $\begin{array}{l}\text { Cone } \\
\\
34\end{array}$ & $\begin{array}{l}\text { Cone } \\
\quad 34\end{array}$ & $\begin{array}{r}\text { Percent } \\
25.9\end{array}$ \\
\hline$A-4$ & ..... do & 2 & $\left\{\begin{array}{r}0.6 \\
.6\end{array}\right.$ & $\begin{array}{l}1.9 \\
2.4\end{array}$ & $\begin{array}{r}10.0 \\
9.8\end{array}$ & $\begin{array}{l}17.4 \\
16.5\end{array}$ & .10 & 33 & 32 to 33 & 32.5 \\
\hline$B-1$ & Metal drum.. & 48 & $\left\{\begin{array}{l}0 \\
.1\end{array}\right.$ & $\begin{array}{l}5.4 \\
8.1\end{array}$ & $\begin{array}{l}15.3 \\
15.5\end{array}$ & $\begin{array}{l}14.8 \\
17.2\end{array}$ & 1.90 & 30 to 31 & 30 to 31 & 18.6 \\
\hline$D-1$ & ...... do & 48 & $\left\{\begin{array}{l}0 \\
1.7\end{array}\right.$ & $\begin{array}{r}7.5 \\
12.5\end{array}$ & $\begin{array}{l}15.5 \\
14.5\end{array}$ & $\begin{array}{l}16.6 \\
16.4\end{array}$ & 0.71 & 37 & 37 & 24.0 \\
\hline$E-2$ & Bag -- & 48 & $\left\{\begin{array}{l}0.8 \\
2.1\end{array}\right.$ & $\begin{array}{l}6.7 \\
8.4\end{array}$ & $\begin{array}{l}27.3 \\
27.2\end{array}$ & $\begin{array}{l}16.6 \\
16.3\end{array}$ & .87 & 26 & 27 & 30.5 \\
\hline$F-1$ & Metal drum.. & 48 & $\left\{\begin{array}{l}0.2 \\
3.6\end{array}\right.$ & $\begin{array}{l}17.6 \\
21.8\end{array}$ & $\begin{array}{l}18.0 \\
16.2\end{array}$ & $\begin{array}{l}13.9 \\
11.5\end{array}$ & 1.53 & $\begin{array}{l}26 \\
28\end{array}$ & $\begin{array}{l}26 \\
28\end{array}$ & 21.0 \\
\hline$F-2$ & ..... do . & $1 / 4$ & $\left\{\begin{array}{l}0 \\
0\end{array}\right.$ & $\begin{array}{l}2.5 \\
2.3\end{array}$ & $\begin{array}{l}26.5 \\
23.9\end{array}$ & $\begin{array}{l}24.1 \\
26.8\end{array}$ & 1.03 & 27 & 27 & 36.9 \\
\hline$G-1$ & Bag... & 6 & $\left\{\begin{array}{l}0 \\
.2\end{array}\right.$ & $\begin{array}{l}3.4 \\
3.5\end{array}$ & $\begin{array}{l}13.5 \\
12.7\end{array}$ & $\begin{array}{l}16.4 \\
16.1\end{array}$ & 0.27 & 27 & 27 & 26.0 \\
\hline$H-1$ & ..... do & 7 & $\left\{\begin{array}{l}0 \\
.1\end{array}\right.$ & $\begin{array}{l}2.2 \\
3.6\end{array}$ & $\begin{array}{l}12.9 \\
15.3\end{array}$ & $\begin{array}{l}19.1 \\
19.7\end{array}$ & 1.86 & 29 & 29 & 32.9 \\
\hline$I-1$ & $\ldots . . . d c$ & 49 & $\left\{\begin{array}{l}0.7 \\
3.4\end{array}\right.$ & $\begin{array}{l}9.6 \\
9.0\end{array}$ & $\begin{array}{l}12.6 \\
11.0\end{array}$ & $\begin{array}{l}16.0 \\
15.2\end{array}$ & 0.03 & Above 38 & Above 38 & 14.4 \\
\hline$L-1$ & ...do & 13 & $\left\{\begin{array}{r}2.4 \\
22.7\end{array}\right.$ & $\begin{array}{l}25.7 \\
24.1\end{array}$ & $\begin{array}{l}15.1 \\
10.7\end{array}$ & $\begin{array}{l}12.1 \\
10.3\end{array}$ & 1.02 & 319 to 23 & 20 & 22.8 \\
\hline$M-1$ & Metal & 49 & $\left\{\begin{array}{r}0.6 \\
.4\end{array}\right.$ & $\begin{array}{r}8.8 \\
11.0\end{array}$ & $\begin{array}{l}11.5 \\
15.0\end{array}$ & $\begin{array}{l}10.8 \\
17.2\end{array}$ & 1.03 & Above 35 & Above 35 & 12.8 \\
\hline $0-2$ & Bag .. & $1 / 4$ & .1 & 2.6 & 6.1 & 10.4 & 1.08 & Above 36 & Above 36 & 21.7 \\
\hline$R-2$ & $\cdots$ & 3 & $\left\{\begin{array}{l}3.3 \\
1.9\end{array}\right.$ & $\begin{array}{l}21.3 \\
20.6\end{array}$ & $\begin{array}{l}15.4 \\
15.6\end{array}$ & $\begin{array}{l}11.9 \\
12.3\end{array}$ & $\begin{array}{l}\text { 1. } 27 \\
1.27\end{array}$ & 31 & 31 & 25.8 \\
\hline$W-1$ & ...... do & 48 & $\begin{array}{l}0.4 \\
1.1\end{array}$ & $\begin{array}{l}11.7 \\
13.5\end{array}$ & $\begin{array}{l}19.8 \\
19.5\end{array}$ & $\begin{array}{l}15.5 \\
16.0\end{array}$ & 0.88 & 31 & 31 & 26.3 \\
\hline$x-1$ & Metal drum .- & 34 & $\begin{array}{l}0.6 \\
1.1\end{array}$ & $\begin{array}{l}2.3 \\
2.7\end{array}$ & $\begin{array}{l}8.4 \\
8.0\end{array}$ & $\begin{array}{l}14.7 \\
16.0\end{array}$ & 0 & 27 to 28 & 27 & 27.1 \\
\hline $\mathrm{Z}-1$ & Bag.. & $1 / 2$ & ${ }^{0} .2$ & $\begin{array}{l}11.7 \\
13.0\end{array}$ & $\begin{array}{l}14.5 \\
15.3\end{array}$ & $\begin{array}{l}13.0 \\
14.6\end{array}$ & 2.13 & 31 & 31 & 18.8 \\
\hline
\end{tabular}

1 In most cases"the bags were of burlap lined with moisture-proof paper.

${ }^{2}$ First values obtained after mixing 1 hour, soaking 19 hours, and mixing 4 hours; second values after 1-hour slaking only.

3 Unable to obtain satisfactory end point. 
mortars marketed in the dry condition

\begin{tabular}{|c|c|c|c|c|c|c|c|c|c|}
\hline \multirow[b]{2}{*}{$\begin{array}{l}\text { Time } \\
\text { of set } \\
\text { of } \\
\text { mor- } \\
\text { tars } \\
\text { used } \\
\text { for } \\
\text { trowel- } \\
\text { ing }\end{array}$} & \multicolumn{2}{|c|}{$\begin{array}{l}\text { Troweling; } \\
\text { spreading and } \\
\text { reducing layer }\end{array}$} & \multirow[b]{2}{*}{$\begin{array}{l}\text { Water } \\
\text { con- } \\
\text { tent of } \\
\text { mor- } \\
\text { tars } \\
\text { used in } \\
\text { trowel- } \\
\text { ing } \\
\text { tests }\end{array}$} & \multirow[b]{2}{*}{$\begin{array}{l}\text { Flow- } \\
\text { table } \\
\text { read- } \\
\text { ing }\end{array}$} & \multicolumn{2}{|c|}{$\begin{array}{l}\text { Troweling and drying } \\
\text { properties }\end{array}$} & \multicolumn{3}{|c|}{ Dipping consistency } \\
\hline & $\begin{array}{c}1 / 4^{\prime \prime} \text { to } \\
1 / 8^{\prime \prime} \\
\text { and } \\
1 / 4^{\prime \prime} \text { to } \\
1 / 6^{\prime \prime} \text { in } \\
1 \text { stroke } \\
\text { and } \\
1 / 4^{\prime \prime} \text { to } \\
1 / 8^{\prime \prime} \text { in } \\
25 \\
\text { strokes }\end{array}$ & $\begin{array}{l}\text { From- } \\
14^{\prime \prime} \text { to } \\
1116^{\prime \prime} \\
\text { in } 37 \\
\text { strokes }\end{array}$ & & & Curled & Cracked & $\begin{array}{c}\text { Ob- } \\
\text { tained } \\
\text { easily }\end{array}$ & $\begin{array}{c}\text { Water- } \\
\text { con- } \\
\text { tent of } \\
\text { mor- } \\
\text { tars }\end{array}$ & Workability \\
\hline (12) & (13) & (14) & (15) & (16) & (17) & (18) & (19) & (20) & (21) \\
\hline $\begin{array}{c}\text { Minutes } \\
1\end{array}$ & Good.. & Fair & $\begin{array}{r}\text { Percent } \\
24.4\end{array}$ & 100 & No & Slightly & Yes_. & $\begin{array}{c}\text { Percent } \\
30.4\end{array}$ & Good. \\
\hline 5 & ... do & Good.. & 32.5 & 26 & .....do do. & -....do & -... do _ & 59.1 & $\begin{array}{l}\text { G oo d. V e r y } \\
\text { sticky. }\end{array}$ \\
\hline 10 & -...do do... & .... do & 25.6 & 86 & ...... do & -.... do & ... do - & 31.3 & Good. \\
\hline 8.5 & ...do_... & -...do_.. & 20.9 & 78 & Moderately. & Badly. & -_do_- & 32.4 & Do. \\
\hline 10 & _._do & -_.do_.. & 33.3 & 62 & Slightly & Moderately & No_.. & 49.2 & $\begin{array}{l}\text { Poor. Did not } \\
\text { stay in suspen- } \\
\text { sion. }\end{array}$ \\
\hline 5 & -..do do & .... do & 21.9 & 95 & No...... & No.... & Yes... & 27.7 & Good. \\
\hline 3 & ... do do... & Fair... & 40.4 & 84 & ......do_. & ...... do & -._do_. & 60.1 & Do. \\
\hline 10 & -...do do... & Good.- & 36.3 & 70 & Moderately. & Badly. & No_.. & 42.4 & $\begin{array}{l}\text { Poor. Did not } \\
\text { stay in suspen- } \\
\text { sion. }\end{array}$ \\
\hline 3 & ...do... & ... do & 39.9 & 66 & ..... do & _do & -._do_. & 53.8 & $\begin{array}{l}\text { Fair. Dried too } \\
\text { rapidly. }\end{array}$ \\
\hline 5 & ....do_.. & Fair_.- & 21.9 & 80 & No & Slightly & Yes... & 42. 3 & Good. \\
\hline 1 & ....do_.. & ....do do.. & 26.0 & 110 & ..... do & No & _._do_- & 35.3 & $\begin{array}{l}\text { Fair. Dried too } \\
\text { rapidly. }\end{array}$ \\
\hline 3 & ... do & Good.- & 16.6 & 64 & No..... & ............. & No_.. & 20.7 & Good. \\
\hline 30 & ....do & ....do _... & 25.0 & 77 & Moderately. & Moderately. & Yes.. & 43.4 & Do. \\
\hline 3 & ....do ... & ....do & 25.8 & 24 & No_.. & Badly.. & ...do_. & 36.6 & $\begin{array}{l}\text { Fair. Did not } \\
\text { stay in suspen- } \\
\text { sion. }\end{array}$ \\
\hline 3 & ....do & ....do_... & 43.0 & 66 & Slightly.. & .... do & No... & 50.0 & Poor. \\
\hline 20 & _._do_.. & Fair & 28.0 & 77 & No & No_... & Yes.. & 42.8 & $\begin{array}{l}\text { Fair. Dried too } \\
\text { slowly. }\end{array}$ \\
\hline 16 & $\ldots$. do _.. & Good.. & 20.1 & 64 & ... do. & ..... do & _._do_. & 32.4 & Good. \\
\hline
\end{tabular}


(b) SIEVE ANALYSIS

The results of the sieve analysis are given in table 1 , columns 4, 5, 6 , and 7 . The differences between the first and second series of values for each mortar are accounted for by the fact that the longer time of soaking and mixing caused a gradual breaking down of the particles. This disintegration was more pronounced in some mortars than in others, as illustrated by mortar $D-1$ versus $X-1$. The disintegration also proceeded further in the mortars containing the greater fractions of coarse particles, as illustrated by mortar $L-1$ versus $G-1$. In a number of instances (examples $A-4, F-1, L-1$, etc.) the percentages of the fractions retained on the No. 100 and No. 200 sieves were increased at the expense of the coarser fractions when the mortar was mixed for the longer period. Although no values for material retained on the No. 20 sieve are shown in the table, in no case was this residue as much as 0.5 percent; in fact, for most of the mortars no residue was noted. No significant relation was apparent between percentage of material not passing the No. 200 sieve and other properties, although in most cases the time of set of the mortars was shortest in those containing the greatest quantity of coarse particles. That no definite relation existed was not surprising, since the mortars contain different amounts of sodium silicate and other ingredients which tended to upset any such relation.

\section{(c) SOLUBLE ALKALI CONTENT}

The soluble alkali content of the mortars, in terms of sodium oxide, ranged from 0 to 1.90 percent. This free alkali in all probability represented in most cases only a portion of that originally added. As shown by Geller and Caldwell, ${ }^{9}$ considerable amounts of alkali can be absorbed by clays and its presence not detected by an indicator.

\section{(d) PYROMETRIC-CONE EQUIVALENT}

The pyrometric-cone equivalent (pce, or softening point) of the mortars listed in table 1 , columns 9 and 10 , ranged from 19 to above 38 for the uncalcined material and from 20 to above 38 for the calcined mortars. The end points obtained indicate little difference in pce between the uncalcined and calcined materials. In some cases, however, the end points of the uncalcined material were more difficult to obtain because of the tendency of the cones to twist and curl.

\section{(e) FUSION-BLOCK TEST}

The conclusions drawn from the appearance of the mortar in the fusion-block tests, relative to adherence, flow, shrinkage, and cracking: (see table 3) correlate in general so well with those drawn from the pier specimens that no separate discussion is considered necessary.

(f) FLOW-TABLE TEST

The results of the flow-table test of the mortars in a troweling consistency are given in table 1, column 16 . The values range from 24 to 110. This range is rather broad; consequently it would be impracticable to specify a troweling consistency for different mortars based on a definite flow-table reading, as was the original intention when the tests were started.

\section{(g) TROWELING}

(1) Appearance before drying.-The results of the troweling tests are given in table 1, columns 13 and 14 . The troweling tests gave

\footnotetext{
- Absorption of sodium hydroxide by kaolins, J. Am. Ceram. Soc. 4, 468 (1921).
} 


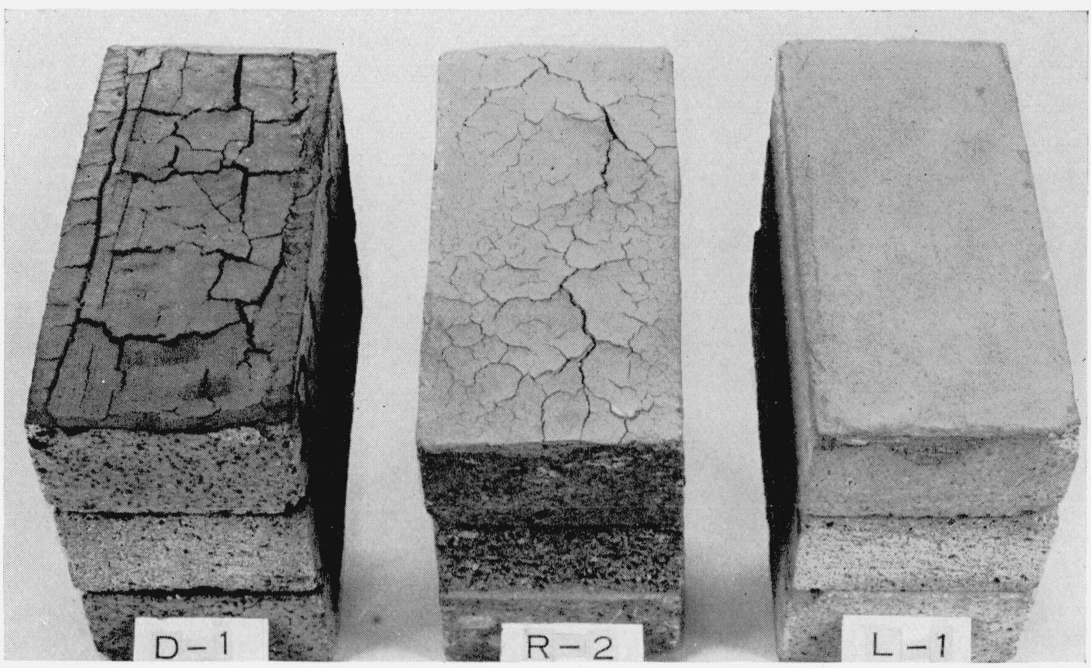

FIgURE 1.-Desirable drying properties are illustrated by mortar $L-1$ and undesirable ones by mortars $D-1$ and $R-2$. 
both an indication of the comparative ease with which a mortar could be satisfactorily spread, and of its water retentiveness. With the mortars in a troweling consistency, as judged by the investigator, there was no difficulty in spreading and reducing layers from $1 / 4$ to $1 / 8$ in. in 1 stroke, from $1 / 4$ to $1 / 16$ in. in 1 stroke, or from $1 / 4$ to $1 / 8$ in. in 25 strokes, when a mechanical trowel was used. When, however, the layer was reduced from $1 / 4$ to $1 / 16$ in. in 37 strokes, five of the mortars $(A-3, F-2$, $I-1, L-1, X-1)$ showed distinct signs of deterioration as far as their working properties were concerned.

(2) Appearance after drying.-Observations on the tendency of the mortars to curl and crack are given in table 1, columns 17 and 18 , respectively. These observations were made on the mortar caps of the thicknesses produced by the mechanical troweling tests (see table 1 , columns 13 and 14). The following ratings, based on the appearance of the mortars after drying on the brick, were given to differentiate the several degrees to which the mortars were curled or cracked: "no", "slightly", "moderately", and "badly." The mortars as a whole showed remarkably little curling, 13 of the 17 mortars being either free or practically free of this undesirable feature. Serious cracking, on the other hand, occurred in 7 of the 17 mortars during drying. The extremes in appearance after drying are illustrated by the three mortars in figure 1.

\section{(h) DIPPING}

The observations given in table 1 , column 19 , indicate that 5 of the 17 mortars were converted from a troweling to a dipping consistency with difficulty, requiring at least half an hour of mixing with water to produce the conversion. The workability (column 21) of the mortars when in a dipping consistency varied widely, with seven of them considered as unsatisfactory. In 3 of these 7 mortars the solids had a decided tendency to separate from the liquid, requiring almost constant agitation of the suspension during the process of dipping the brick. In two cases $(H-1, L-1)$ the water retention was poor, as indicated by too rapid drying of the mortars. Mortar $X-1$, however, was of the opposite type, drying so slowly that it oozed almost completely from the joints of brick piers. This particular mortar could not be classed as smooth-working, since, starting with a troweling consistency, the process of mixing for one-half hour and screening to break up the lumps failed to produce a satisfactory slip consistency.

\section{(i) TRANSVERSE STRENGTH AND LINEAR SHRINKAGE}

In table 2 are given the transverse strengths of the neat-mortar bars, previously heated at various temperatures and cooled. In each case three values are given: (1) the average for not less than five bars broken with the surface that was originally at the bottom in compression (the "inverted" position); (2) a similar average for bars with the surface that was originally at the bottom in tension (the "original" position); and (3) the average for both positions. With comparatively few exceptions, the strength was significantly greater when the bars were broken in the "original" position. This difference in strength may be related to the differences in concentration of the alkali salts near the two surfaces. ${ }^{10}$

10 Properties of air-setling refractory bonding mortars of the wet type, J. Research NBS 23, 7 (1939) RP1219. 
The strength of the mortar bars (average for the two positions) after drying at $105^{\circ} \mathrm{C}$. ranged from 250 to $4,990 \mathrm{lb} / \mathrm{in}^{2}$. The mortars that were received in burlap sacks and stored in the laboratory for an appreciable period of time (table 1, column 2) showed much lower dry strengths, as a group, than those stored in sealed metal drums. ${ }^{11}$

TABLE 2.-Transverse strength of neat mortar bars and two-half-brick-and-mortar assemblages, and length changes of mortars

\begin{tabular}{|c|c|c|c|c|c|c|c|c|c|c|c|c|}
\hline \multirow[t]{2}{*}{ Mortar } & \multicolumn{4}{|c|}{$\begin{array}{l}\text { Transverse strength, } 1 \\
\text { neat-mortar bars after } \\
\text { heating at }{ }^{\circ} \mathrm{C}\end{array}$} & \multicolumn{5}{|c|}{$\begin{array}{l}\text { Trans verse strength, two-half-brick-and-mortar } \\
\text { assemblage, after heating at }{ }^{\circ} \mathrm{C} \text {, and manner of } \\
\text { failure? }\end{array}$} & \multicolumn{3}{|c|}{$\begin{array}{l}\text { Length } \\
\text { changes }{ }^{3} \\
\text { after } \\
\text { heating } \\
\text { at- }\end{array}$} \\
\hline & 105 & 750 & 1,000 & 1,350 & 105 & 750 & 1,000 & 1,350 & 1,500 & $105^{\circ}$ & ${ }_{\mathrm{C}}^{750^{\circ}}$ & ${ }^{1,350^{\circ}}$ \\
\hline$A-3$ & $\left\{\begin{array}{r}\text { lb/in. } .^{2} \\
280 \\
785 \\
560\end{array}\right.$ & $\begin{array}{r}l b / \text { in }^{2} \\
540 \\
745 \\
645\end{array}$ & \begin{tabular}{|r}
$l b /$ in. \\
1,320 \\
2,080 \\
1,700
\end{tabular} & $\begin{array}{r}l b / \text { in. }^{2} \\
1,715 \\
1,700 \\
1,705\end{array}$ & $\begin{array}{r}\text { lb/in. }{ }^{2} \\
45 \\
\mathbf{M}\end{array}$ & $\begin{array}{r}l b / \text { in }^{2} \\
45 \\
\mathbf{M}\end{array}$ & $\begin{array}{r}\text { lb/in. }{ }^{2} \\
30 \\
\mathrm{M}\end{array}$ & $\begin{array}{l}\text { lb/in. }{ }^{2} \\
\text { B \& } 260\end{array}$ & $\begin{array}{r}l b / \text { in }^{2} \\
390 \\
\mathrm{M}\end{array}$ & $\begin{array}{l}\% \\
3.0\end{array}$ & $\begin{array}{c}\% \\
+0.2\end{array}$ & $\begin{array}{c}\% \\
+5.5\end{array}$ \\
\hline$A-4$ & $\begin{array}{l}2,170 \\
2,040 \\
2,105\end{array}$ & $\begin{array}{l}1,120 \\
1,000 \\
1,060\end{array}$ & $\begin{array}{l}3,035 \\
2,610 \\
2,825\end{array}$ & $\begin{array}{l}3,575 \\
2,805 \\
3,190\end{array}$ & $\begin{array}{r}55 \\
\mathrm{~J}\end{array}$ & $\begin{array}{l}0 \\
\mathbf{J}\end{array}$ & $\begin{array}{l}0 \\
\mathrm{~J}\end{array}$ & $\stackrel{80}{\mathrm{~J}}$ & $J \& \stackrel{415}{M}$ & 4.9 & +.2 & +1.4 \\
\hline$B-1$. & $\left\{\begin{array}{l}1,500 \\
1,950 \\
1,725\end{array}\right.$ & $\begin{array}{l}1,445 \\
1,785 \\
1,615\end{array}$ & $\begin{array}{l}2,350 \\
2,350 \\
2,350\end{array}$ & $\begin{array}{l}3,110 \\
3,510 \\
3,310\end{array}$ & $\begin{array}{r}425 \\
\mathrm{~B}\end{array}$ & $\begin{array}{r}380 \\
\mathrm{~B} \& \mathrm{~J}\end{array}$ & $\begin{array}{r}320 \\
\mathrm{~B}\end{array}$ & B \& $\stackrel{365}{M}$ & & 3.4 & +.1 & $\begin{array}{l}1.2 \\
\end{array}$ \\
\hline$D-1$ & $\begin{array}{l}1,035 \\
1,475 \\
1,275\end{array}$ & $\begin{array}{l}1,570 \\
1,740 \\
1,655\end{array}$ & $\begin{array}{l}2,450 \\
2,875 \\
2,740\end{array}$ & $\begin{array}{r}4,450 \\
1,655 \\
1,555\end{array}$ & B \& $\mathrm{M}$ & $\mathrm{B}, \mathrm{M}, \& \mathrm{~J}$ & $\begin{array}{r}185 \\
\mathrm{~B}\end{array}$ & $\begin{array}{r}465 \\
\mathrm{~B}\end{array}$ & & 8.0 & .5 & 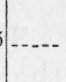 \\
\hline$E-2$ & $\begin{array}{r}625 \\
1,050 \\
835\end{array}$ & $\begin{array}{l}270 \\
295 \\
280\end{array}$ & $\begin{array}{l}270 \\
260 \\
265\end{array}$ & $\begin{array}{l}720 \\
750 \\
735\end{array}$ & $M \& J$ & $M \& \mathrm{~J}$ & $\begin{array}{l}0 \\
\mathrm{~J}\end{array}$ & $M \stackrel{105}{\mathrm{M}} \mathrm{J}$ & & 7.3 & +1.2 & 2.0 \\
\hline$F-1$ & $\left\{\begin{array}{r}930 \\
1,415 \\
1,195\end{array}\right.$ & $\begin{array}{l}520 \\
940 \\
730\end{array}$ & $\begin{array}{r}820 \\
1,250 \\
1,035\end{array}$ & $\begin{array}{l}860 \\
785 \\
820\end{array}$ & $\begin{array}{r}355 \\
\mathrm{~B}\end{array}$ & $\begin{array}{r}145 \\
\mathrm{M}\end{array}$ & $\begin{array}{r}230 \\
\mathbf{M}\end{array}$ & B \& $\begin{array}{r}335 \\
M\end{array}$ & & 2.9 & +0.6 & \begin{tabular}{l|l}
3.9 & 1.9
\end{tabular} \\
\hline$F-2$ & $\begin{array}{r}530 \\
1,060 \\
795\end{array}$ & $\begin{array}{l}530 \\
745 \\
635\end{array}$ & $\begin{array}{l}380 \\
875 \\
625\end{array}$ & $\begin{array}{r}1,030 \\
1,900 \\
5 \\
1,405\end{array}$ & $\begin{array}{r}205 \\
\mathbf{M}\end{array}$ & $M \& J$ & $M \& \stackrel{0}{J}$ & $M \& \stackrel{0}{J}$ & $\begin{array}{r}175 \\
\mathrm{M}\end{array}$ & 2.0 & +.6 & +3.5 \\
\hline$G-1$ & $\begin{array}{l}315 \\
585 \\
450\end{array}$ & $\begin{array}{l}230 \\
355 \\
295\end{array}$ & $\begin{array}{l}680 \\
800 \\
740\end{array}$ & $\begin{array}{l}1,700 \\
2,135 \\
1,920\end{array}$ & $M \& \mathrm{~J}$ & $M \& J$ & $M \& \mathrm{~J}$ & $M \&{ }^{70} \mathrm{~J}$ & 760 & 5.7 & +.5 & 2.1 \\
\hline$H-1$ & $\left\{\begin{array}{l}400 \\
620 \\
510\end{array}\right.$ & $\begin{array}{l}760 \\
750 \\
755\end{array}$ & $\begin{array}{l}1,725 \\
1,420 \\
1,575\end{array}$ & $\begin{array}{l}2,050 \\
1,565 \\
1,805\end{array}$ & $M \& J$ & $\begin{array}{r}20 \\
\mathrm{~J}\end{array}$ & $\begin{array}{l}0 \\
\mathrm{~J}\end{array}$ & $\stackrel{30}{\mathrm{~J}}$ & & 5.5 & .3 & 3.1 \\
\hline$I-1$. & $\begin{array}{l}405 \\
390 \\
400\end{array}$ & $\begin{array}{r}1,115 \\
915 \\
1,015\end{array}$ & $\begin{array}{l}920 \\
785 \\
850\end{array}$ & $\begin{array}{l}2,690 \\
2,560 \\
2,625\end{array}$ & $\begin{array}{r}110 \\
\mathrm{~J}\end{array}$ & $\begin{array}{r}40 \\
\mathbf{J}\end{array}$ & $\begin{array}{l}0 \\
\mathbf{J}\end{array}$ & 75 & $\begin{array}{r}355 \\
\mathrm{M}\end{array}$ & 2.6 & .3 & 0.5 \\
\hline$L-1$ & $\begin{array}{l}600 \\
870 \\
750\end{array}$ & $\begin{array}{l}325 \\
365 \\
345\end{array}$ & $\begin{array}{l}430 \\
575 \\
500\end{array}$ & $\begin{array}{l}1,360 \\
1,155 \\
1,260\end{array}$ & $\mathrm{~J} \& \mathrm{M}$ & $M \& J$ & $\stackrel{0}{\mathrm{M}}$ & $M \quad \begin{array}{l}125 \\
\text { \& } J\end{array}$ & & 2. 6 & +.3 & 1.8 \\
\hline$M-1$ & $\left\{\begin{array}{l}2,610 \\
3,830 \\
3,220\end{array}\right.$ & $\begin{array}{l}2,610 \\
2,700 \\
2,650\end{array}$ & $\begin{array}{l}2,910 \\
3,380 \\
3,145\end{array}$ & $\begin{array}{r}5,730 \\
7,540 \\
6 \quad 6,635\end{array}$ & $\mathrm{~B}, \mathrm{M}, \stackrel{480}{\& \mathrm{~J}}$ & $\mathrm{~B}, \mathrm{M}, \stackrel{355}{\mathrm{~J}}$ & B \& $\mathrm{J}$ & B, J, \& $\stackrel{410}{M}$ & $\mathrm{~B}, \mathrm{M}, \begin{array}{r}500 \\
\& \mathrm{~J}\end{array}$ & 4.5 & +.8 & 2.3 \\
\hline $0-2$ & $\left\{\begin{array}{l}5,255 \\
4,775 \\
4,990\end{array}\right.$ & $\begin{array}{l}1,855 \\
3,510 \\
2,685\end{array}$ & $\begin{array}{l}2,195 \\
4,435 \\
3,315\end{array}$ & $\begin{array}{l}5,940 \\
4,740 \\
5,275\end{array}$ & $\begin{array}{r}240 \\
\mathrm{~J}\end{array}$ & $\begin{array}{r}100 \\
J\end{array}$ & $\begin{array}{r}110 \\
\mathrm{~J}\end{array}$ & B, J, \& $\begin{array}{r}350 \\
\end{array}$ & & 7.0 & 1.2 & 5.5 \\
\hline$R-2$ & $\left\{\begin{array}{r}675 \\
900 \\
5785\end{array}\right.$ & $\begin{array}{l}700 \\
780 \\
740\end{array}$ & $\begin{array}{r}990 \\
1,075 \\
1,030\end{array}$ & $\begin{array}{l}1,100 \\
1,020 \\
1,060\end{array}$ & $\begin{array}{r}120 \\
\mathbf{M}\end{array}$ & $M \& J$ & $M \quad \begin{array}{r}150 \\
\&\end{array}$ & M \& J & & 6.2 & 0.2 & 1.3 \\
\hline K & $\begin{array}{l}210 \\
290 \\
250\end{array}$ & $\begin{array}{l}530 \\
575 \\
555\end{array}$ & $\begin{array}{l}1,040 \\
1,185 \\
1,115\end{array}$ & $\begin{array}{l}2,040 \\
1,720 \\
1,880\end{array}$ & $\mathrm{~J} \& \mathrm{3} \mathrm{3}$ & $\begin{array}{r}15 \\
\mathrm{~J}\end{array}$ & 0 & $\mathrm{~J} \& \stackrel{60}{\mathrm{M}}$ & & 3.8 & .3 & 3.3 \\
\hline
\end{tabular}

See footnotes at end of table. 11 Effect of water content and mixing time on properties of air-setting refractory mortars containing sodium
silicate, Bul. Am. Ceram. Soc. $\mathbf{1 9 ,} 430(1940)$. 
TABLE 2. (Continued)-Transverse strength of neat mortar bars and two-half-brickand-mortar assemblages, and length changes of mortars

\begin{tabular}{|c|c|c|c|c|c|c|c|c|c|c|c|c|}
\hline \multirow[t]{2}{*}{ Mortar } & \multicolumn{4}{|c|}{$\begin{array}{l}\text { Transverse strength, } \\
\text { neat-mortar bars after } \\
\text { heating at }{ }^{\circ} \mathrm{C}\end{array}$} & \multicolumn{5}{|c|}{$\begin{array}{l}\text { Transverse strength, two-half-brick-and-mortar } \\
\text { assemblage, after heating at }{ }^{\circ} \mathrm{C} \text {, and manner of } \\
\text { failure }\end{array}$} & \multicolumn{3}{|c|}{$\begin{array}{l}\text { Length } \\
\text { changes } \\
\text { after } \\
\text { heating } \\
\text { at- }\end{array}$} \\
\hline & 105 & 750 & 1,000 & 1,350 & 105 & 750 & 1,000 & 1,350 & 1,500 & $\begin{array}{c}105^{\circ} \\
\mathrm{C}\end{array}$ & $750^{\circ}$ & $1,350^{\circ}$ \\
\hline$X-1$ & $\left\{\begin{array}{r}l b / \text { in }^{2} \\
710 \\
1,180 \\
950\end{array}\right.$ & $\begin{array}{r}\text { lb/in. }{ }^{2} \\
500 \\
555 \\
525\end{array}$ & \begin{tabular}{|r|}
$l b /$ in. \\
1,460 \\
1,425 \\
1,440
\end{tabular} & $\left.\begin{array}{r}l b / \text { in. } \\
3,485 \\
2,970 \\
3,330\end{array}\right\}$ & $\begin{array}{r}l b / \text { in. }^{2} \\
290 \\
\mathrm{M}\end{array}$ & $\begin{array}{r}l b / \text { in }^{2}{ }^{2} \\
\mathrm{~J} \& \mathrm{M}\end{array}$ & $\begin{array}{r}l b / \text { in. } .^{2} \\
\mathrm{M} \& \mathrm{~J}\end{array}$ & $\begin{array}{c}l b / \text { in }^{2} \\
\text { B \& } \mathrm{M}\end{array}$ & $l b /$ in $^{2}$ & $\begin{array}{l}\% \\
4.4\end{array}$ & $\begin{array}{c}\% \\
.2\end{array}$ & $\begin{array}{l}\% \\
6.1\end{array}$ \\
\hline$Z-1$ & $\left\{\begin{array}{r}1,965 \\
2,700 \\
32,335\end{array}\right.$ & $\begin{array}{l}1,900 \\
1,850 \\
1,880\end{array}$ & $\begin{array}{l}2,310 \\
2,275 \\
2,295\end{array}$ & $\left.\begin{array}{l}2,805 \\
2,320 \\
2,560\end{array}\right\}$ & $\mathrm{B}, \mathrm{J}, \& \mathrm{3} \mathrm{M}$ & B, J, \& $\stackrel{205}{\mathrm{M}}$ & $\mathrm{B}, \mathrm{M}, \begin{array}{r}320 \\
\& \mathrm{~J}\end{array}$ & $\mathrm{~B}, \mathrm{M}, \begin{array}{r}305 \\
\mathrm{~J}\end{array}$ & & 5.0 & .4 & 2.6 \\
\hline
\end{tabular}

1 The 3 values for each mortar at the various temperatures represent, in the order given, the average of:

(1) 5 specimens broken with the surface that was originally at the bottom during drying, in compression;

(2) 5 specimens with the surface that was originally on the bottom, in tension; (3) all specimens.

$2 \mathrm{~B}$, J, and $\mathrm{M}$ indicate failure occurred in brick, joint, or mortar, respectively.

3 Except the values for $105^{\circ} \mathrm{C}$, which represent the drying shrinkage, the length changes given represent changes between the dry length and the length after heating. "+" indicates expansion. Measurements made of bar specimens of neat mortars. For water content, see column 11 of table 1.

4 Overfired.

5. Average of 7 specimens broken over a 3-in. span.

A verage of 5 specimens.

The majority of the mortars were weaker after heating at $750^{\circ} \mathrm{C}$ than when dried at $150^{\circ} \mathrm{C}$. The air-setting strength was generally equalled or exceeded, however, by heating at $1,000^{\circ}$ and $1,350^{\circ} \mathrm{C}$. In this respect the trend of strength-temperature relations (see footnote 10) is similar to that found in previous tests on air-setting refractory mortars of the wet type. The following is a grouping of the 17 mortars, of the dry type, according to strength changes resulting from heat treatment at three temperatures, compared with the dry strength: (1) Eleven had lower strength at $750^{\circ}$ and higher strength at $1,000^{\circ}$ and $1,350^{\circ} \mathrm{C}$; (2) Four had increased strength with increased temperature; and (3) two had lower strength with increased temperature.

The ranges of the coefficient of variation in transverse strength of the neat-mortar bars preheated at the several temperatures are as follows: (1) 0.7 to 21.1 percent ( $\%$ of them below 10 percent) at $105^{\circ} \mathrm{C}$, (2) 3.2 to 19.8 percent ( $4 / 5$ of them below 10 percent) at $750^{\circ} \mathrm{C}$, (3) 1.7 to 37.3 percent ( $3 / 5$ of them below 10 percent) at $1,000^{\circ} \mathrm{C}$, (4) 1.0 to 34 percent ( $3 / 4$ of them below 10 percent) at $1,350^{\circ} \mathrm{C}$.

Values for the changes in length of the mortar bars preheated at $105^{\circ}, 750^{\circ}$, and $1,350^{\circ} \mathrm{C}$ are given in table 2 , each value being the average length change of three bars. The shrinkages of the mortar bars dried overnight at approximately $105^{\circ} \mathrm{C}$ ranged from 2.0 to 8.0 percent. Preheating at $750^{\circ} \mathrm{C}$ resulted in little additional shrinkage, eight mortars in fact showing a slight expansion. After heating at $1,350^{\circ} \mathrm{C}$, all but four mortars $(A-3, A-4, F-2$, and $D-1$, which were badly warped) showed shrinkages ranging from 0.5 to 6.1 percent. It is rather significant that all of the mortars, except $A-4$, having a drying shrinkage greater than 5 percent cracked moderately or badly, whereas those, except $W-1$, having 5 percent or less showed either no cracks or barely perceptible ones (see column 18, table 1) when the mechanical troweling and drying were completed. 


\section{ASSEMBLAGE OF TWO HALF-BRICK AND MORTAR}

(a) SETTING TIME OF MORTAR, OR WATER-RETENTION TEST

The time required for the mortars, placed between firebrick, to air-set, or stop flowing under load, ranged from 1 to 30 minutes (table 1, column 12); seven, however, set in 3 minutes or less.

Because this test, that is, time of set, or water-retention test, may be made without special equipment, it would be preferable to a mechanical-troweling test, provided it gave the desired information regarding workability. However, some of the mortars which would be rated as satisfactory on the basis of the setting time $(F-2, I-1$, and $X-1)$ were unsatisfactory as far as workability was concerned, as indicated by the mechanical trowel. It appears, therefore, that the time of set is not a satisfactory criterion of workability. Furthermore, the mechanical-troweling test is the more inclusive workability test, since it not only gives information on the water retentiveness of a mortar but also gives information as to its troweling properties, such as ease of spreading and smoothness. Thus there is a lapse of $3 \frac{1}{2}$ minutes between the time a $1 / 4$-in. layer of mortar is placed on the face of a brick and the reduction of this layer to $1 / 16$ in. in 37 strokes of the trowel. If the mortar sets too quickly, it will not give good results in the troweling test, as was indicated by mortars $A-3$ and $L-1$. Therefore, since the time-of-set, or water-retention, test failed to differentiate between mortars of good and poor workability in 3 of the 17 mortars tested, the value of such a test in a specification is questionable.

\section{(b) TRANSVERSE STRENGTH}

The results of the transverse-strength tests made on assemblages of the two half-brick and mortar, preheated simultaneously with the mortar bars, are given in table 2. The strengths of the assemblages after drying at $105^{\circ} \mathrm{C}$ ranged from 35 to $480 \mathrm{lb} / \mathrm{in} .{ }^{2}$, eight of the values being not less than $200 \mathrm{lb} / \mathrm{in}^{2}{ }^{2}$. The assemblages containing 11 of the 17 mortars had the least strength after the $1,000^{\circ} \mathrm{C}$ heat treatment. This is in contrast to the strengths of the neat-mortar bars, whose lowest values were found, in general, after the $750^{\circ} \mathrm{C}$ heat treatment. Furthermore, after the $1,000^{\circ} \mathrm{C}$ heat treatment, seven mortars had no apparent bonding strength - that is, the specimens failed during handling. This is in sharp contrast to the strengths of the air-setting mortars of the wet type, ${ }^{12}$ where none was without some bonding strength and only two had strengths less than $100 \mathrm{lb} /$ in. $^{2}$ after a similar heat treatment.

The strengths of assemblages bonded with six different mortars were obtained after heating at $1,500^{\circ} \mathrm{C}$ for 1 hour. The values showed great increases in strength in comparison with those obtained after heating at $1,350^{\circ} \mathrm{C}$, as given in table 2 .

The ranges of the coefficient of variation in strength of the assemblages previously heated at the several temperatures are as follows: (1) $105^{\circ} \mathrm{C}, 8.3$ to 73 percent; (2) $750^{\circ} \mathrm{C}, 18$ to 79 percent; (3) $1,000^{\circ}$ C, 35 to 65 percent, and (4) $1,350^{\circ} \mathrm{C}, 8.3$ to 64 percent. In general the high coefficients of variation are associated with low mean values.

A direct relation was indicated between the dry strengths $\left(105^{\circ} \mathrm{C}\right)$ of the neat-mortar bars and those of the assemblages, except in two cases $(A-4$ and $O-2)$, where failures occurred in the joint or at the mortar-

12 Properties of air-setting refractory-bonding mortars of the wet type, J. Research NBS 23, 7 (1939) RP1219. 
brick interface. Because of these exceptions, it would appear desirable to state a strength requirement for the assemblage in a specification.

\section{(c) TYPES OF FAILURE}

In testing the cross-breaking strength of the assemblages, the four following types of failure were observed. The fracture occurred (1) in the brick, (2) at the mortar-brick interface, (3) in the mortar, (4) some combination of (1), (2), and (3). In table 2 these types of failure are respectively indicated $\mathrm{B}, \mathrm{J}, \mathrm{M}$ and the proper combination of $\mathrm{B}, \mathrm{J}$, and $\mathrm{M}$.

(d) RELATION OF WATER CONTENT TO SETTING TIME AND TO FLOW

Small changes in the water content of an air-setting refractory mortar may greatly alter some of its properties, such as time of set

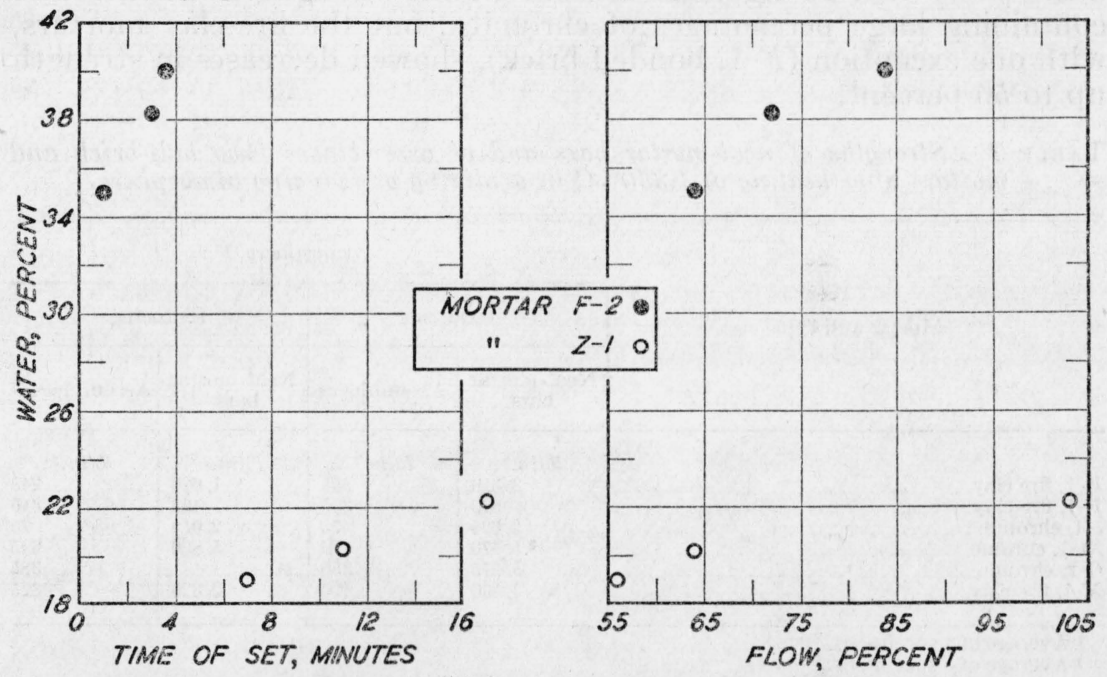

FIGURE 2.-The relation between tempering-water and time of set, and also flow of mortars $F-2$ and $Z-1$.

and flow (consistency). Mortars are differently affected by a uniform change in their water content.

Two mortars, $F-2$ and $Z-1$, containing 40.1 and 20.1 percent of water, respectively (see table 1, column 15), were used in investigating these relations. Figure 2, showing the effect of small changes in tempering-water on the time of set and on the flow of these mortars, indicates that $Z-1$ is more sensitive than $F-2$ to such changes. A 3.2percent increase in the water content of $Z-1$ increased the time of set 10 minutes ( 7 to 17 minutes) and the flow 50 percent (56 to 106 percent), whereas a 5-percent increase in the water content of $F-2$ increased the setting time slightly more than 2 minutes ( 1 to +3 minutes) and the flow only 20 percent ( 64 to 84 percent).

The information thus obtained indicates that attempts to place any limitations on the technical requirements, such as the time of set and its influence on other properties, should not be made without giving some consideration to the factor of the sensitivity of mortars to changes in water content.

(e) EFFECT OF ATMOSPHERE DURING HEATING ON STRENGTH

The results of the transverse-strength tests, reported in table 2, were obtained from mortar specimens heated in an oxidizing atmos- 


\section{Journal of Research of the National Bureau of Standards}

phere. Additional tests were required to determine the effect of a reducing atmosphere.

Three mortars $(I-1, M-1, O-2)$ having a chromite base and three $(B-1, F-1, X-1)$ having a fire-clay base were used for this purpose. The test specimens, consisting of mortar bars and assemblages (two half-brick and mortar), were heated at $1,350^{\circ} \mathrm{C}$ in a strongly reducing atmosphere, which was mechanically controlled. ${ }^{13}$

The results of the transverse-strength tests are given in table 3. For comparison, data (table 2, columns 5 and 9) obtained on similar test specimens heated at $1,350{ }^{\circ} \mathrm{C}$ in an oxidizing atmosphere are included.

These results indicate that the heating at $1,350^{\circ} \mathrm{C}$ in a reducing atmosphere had no significant effect on the strength of the mortars containing large percentages of chromite; but the fire-clay mortars, with one exception ( $F-1$, bonded brick), showed decreases in strength up to 50 percent.

TABLE 3.-Strengths of neat-mortar bars and of assemblages (two half-brick and mortar) after heating at $1,350^{\circ} \mathrm{C}$ in oxidizing or reducing atmosphere

\begin{tabular}{|c|c|c|c|c|}
\hline \multirow{3}{*}{ Mortar and type } & \multicolumn{4}{|c|}{ Atmosphere } \\
\hline & \multicolumn{2}{|c|}{ Oxidizing } & \multicolumn{2}{|c|}{ Reducing } \\
\hline & $\underset{\text { bars }}{\text { Neat-mortar }}$ & Assemblages & $\underset{\text { bars } 1}{\text { Neat-mortar }}$ & Assemblages ${ }^{2}$ \\
\hline $\begin{array}{l}B-1, \text { fire clay } \\
F-1, \text { fire clay } \\
I-1 \text {, chrome } \\
M-1 \text {, chrome } \\
O-2 \text {, chrome } \\
X-1 \text {, fire clay }\end{array}$ & $\begin{array}{r}l b / \text { in } .^{2} \\
3,310 \\
820 \\
2,625 \\
35,670 \\
5,275 \\
3,330\end{array}$ & $\begin{array}{r}\text { lb/in. }{ }^{2} \\
365 \\
335 \\
75 \\
410 \\
350 \\
420\end{array}$ & $\begin{array}{r}\text { lb/in. } .^{2} \\
1,620 \\
485 \\
2,950 \\
5,800 \\
2,320\end{array}$ & $\begin{array}{r}\text { lb/in. }{ }^{2} \\
245 \\
340 \\
75 \\
295 \\
385 \\
325\end{array}$ \\
\hline
\end{tabular}

1 Average of 8 specimens.

2 Average of 5 specimens.

3 Represents average of a different lot of specimens from that given in table 2 .

\section{PIER OF THREE BRICK AND MORTAR}

The results of the visual examination of the mortars used in the piers are given in table 4.

The quality of the mortars, as indicated by cracking, already was evident after air-drying. Four of the mortars $(D-1, G-1, H-1, O-2)$ in the group having the greatest drying shrinkage cracked badly in the $1 / 8$-in. joints, but, with the exception of $D-1$, showed no serious cracking in the $1 / 11^{-}$-in. joints. On the other hand, mortar $R-2$, in the same shrinkage group, had cracked badly in the $1 / 16$-in. joint only.

Observations on the adherence of mortar to brick showed that the nonadherent areas of the mortar caps amounted to 25 to 50 percent for six mortars and an estimated 5 to 10 percent for four others after drying at $105^{\circ} \mathrm{C}$. No improvement in the percentage of adherence resulted after heating at the higher temperatures. In fact, the tendency for more of the cap to become loosened was increased. Apparently the lack of adherence of the mortar caps was no indication that low strengths (table $2, B-1, D-1$ ) of the piers would necessarily follow except $(A-4$ and $O-2)$ where low strength was caused by failure at the mortar-brick interface.

13. By means:of s $\mathrm{CO}_{3}$ meter. 
TABLE 4.-Appearance of mortar in fusion block, cap, and in joints of three-brick-and-mortar assemblages or piers

\begin{tabular}{|c|c|c|c|c|c|c|c|c|c|c|c|c|c|c|c|}
\hline \multirow{3}{*}{$\begin{array}{c}\text { Mor- } \\
\text { tar }\end{array}$} & \multicolumn{3}{|c|}{ Appearance 1 of mortar after drying } & \multicolumn{3}{|c|}{ Appearance 1 of mortar after heating 24 hours at $750^{\circ} \mathrm{C}$} & \multicolumn{3}{|c|}{ Appearances tof mortar after heating 1 hour at $1,350^{\circ} \mathrm{C}$} & \multicolumn{2}{|c|}{\begin{tabular}{|l|l} 
Appearance 1 of mortar after beating 1 hour \\
at 1 $1,500^{\circ} \mathrm{C}$
\end{tabular}} & \multicolumn{4}{|c|}{ Condition 2 of mortar in fusion block after heating at- } \\
\hline & \multicolumn{2}{|c|}{ In joint } & \multirow{2}{*}{ As cap, 38" } & \multicolumn{2}{|r|}{ In joint } & \multirow{2}{*}{ As cap, 36" } & \multicolumn{2}{|c|}{ In joint } & \multirow{2}{*}{ As cap, $18^{\prime \prime}$} & \multirow{2}{*}{ In joint, 18" } & \multirow{2}{*}{ As cap, $18^{\prime \prime}$} & \multirow{2}{*}{$105^{\circ} \mathrm{C}$} & \multirow{2}{*}{$750^{\circ} \mathrm{C}$} & \multirow{2}{*}{$1,350^{\circ} \mathrm{C}$} & \multirow{2}{*}{$1,500^{\circ} \mathrm{C}$} \\
\hline & $46^{\prime \prime}$ & $18^{1 \prime \prime}$ & & $36^{\prime \prime}$ & $18^{\prime \prime}$ & & 36" & $38^{\prime \prime}$ & & & & & & & \\
\hline$A-3$ & Good. & Good... & Very good... & || cracks. & $\|$ and $\perp$ cracks. & Good. & $\perp$ cracks. & $\mid$ | cracks.... & Good.. & || cracks. & Good.. & Good. & Good.. & Good. Slight expansion & Good. Slight expansion. \\
\hline$A^{-4}$ & $\perp$ and $\|$ racks. & || reracks... & $25 \%$ not bonded... & $\perp$ cracks. & ....do & $25 \%$ not bonded.... & $\perp$ and $\|$ cracks. & $\perp$ and $\|$ cracks. & $50 \%$ not bonded. & Bad $\perp$ and $\|$ eracks... & Slighty cracked. $50 \%$ & Good. No adherence. & Good. No adherence. & Good. No adherence. & Good. No adherence. \\
\hline$B-1$ & do & $\perp$ and $\|$ cracks. & $\begin{array}{l}\text { Moderately cracked. } \\
10 \% \text { not bonded. }\end{array}$ & Good. & .....do.. & $\begin{array}{l}\text { Moderately cracked. } \\
25 \% \text { not bonded. }\end{array}$ & do & $\ldots$ do & $\begin{array}{l}\text { Moderately cracked. } \\
25 \% \text { not bonded. }\end{array}$ & $\perp$ crack & Badly cracked.. & Badly eracke & Badly cracked. & Badly cracked & Badly cracked. \\
\hline$D-1$ & Bad $\perp$ and $\|$ eracks. & Bad $\perp$ cracks. & $\begin{array}{l}\text { Badly cracked. } 50 \% \\
\text { not bonded. }\end{array}$ & Bad $\perp$ cracks. & Bad $\perp$ and $\|$ eracks. & $\begin{array}{l}\text { Badly cracked. } 75 \% \\
\text { not bonded. }\end{array}$ & Bad $\perp$ and $\|$ racks. & Bad $\perp$ and \| eracks. & $\begin{array}{l}\text { Baily cracked. } 50 \% \\
\text { not bonded. Glassy. }\end{array}$ & Bad $\perp$ cracks. & $\begin{array}{l}\text { Badly cracked. High } \\
\text { shrinkage. }\end{array}$ & $\ldots . . . \mathrm{do}$ & Badly cracked. & $\begin{array}{l}\text { Badly cracked. High } \\
\text { shrinkage. }\end{array}$ & $\begin{array}{l}\text { Badly cracked. High } \\
\text { shrinkage. }\end{array}$ \\
\hline$E-2$ & $\perp$ and $\|$ eracks. & \begin{tabular}{|c|} 
Moderate $\perp$ and $\|$ \\
eracks.
\end{tabular} & $\begin{array}{l}\text { Slightly cracked. } 10 \% \\
\text { not bonded. }\end{array}$ & $\perp$ and $\|$ rackss. & $\|$ cracks. & $\begin{array}{l}\text { Slightly cracked. } 50 \% \\
\text { not bonded. }\end{array}$ & $\perp$ and $\|$ cracks. & $\perp$ and $\|$ eracks & $\begin{array}{l}\text { Moderately cracked. } \\
75 \% \text { not bonded. }\end{array}$ & $\begin{array}{l}\text { Fused and flowed } \\
\text { from joint. }\end{array}$ & $\begin{array}{l}\text { Fused. High shrink- } \\
\text { age. }\end{array}$ & $\begin{array}{l}\text { No adherence. Mod- } \\
\text { erate shrinkage. }\end{array}$ & $\begin{array}{l}\text { No adherence. Mod- } \\
\text { erate shrinkage. }\end{array}$ & $\begin{array}{l}\text { No adherence. High shrink- } \\
\text { agge }\end{array}$ & Fused and flowed slightly. \\
\hline$F-1$ & Good. & Good. & Very good... & Good.... & aood... & Very good... & \| cracks. Glassy- & $\|$ eracks. Glassy. & $\begin{array}{l}\text { Slightly cracked. } 5 \% \\
\text { not bonded. }\end{array}$ & ......do... & Fused... & Good. Slightly & Moderately cracked... & Moderate shrinkage. Glassy & $\begin{array}{l}\text { Fused and flowed slightly. } \\
\text { Moderate shrinkage. }\end{array}$ \\
\hline$F-2$ & do. & do. & Good. & & || eracks. & do. & $\perp$ and $\|$ cracks. & $\perp$ and $\|$ cracks. & $\begin{array}{l}\text { No cracks. } 100 \% \text { not } \\
\text { not bonded. }\end{array}$ & $\perp \underset{\text { Glassy. }}{\text { and }} \|$ cracks. & $100 \%$ not bonde & Good.... & Good. & Good. No adherence & Good. Glassy. \\
\hline$a^{a-1}$ & $\perp$ and $\|$ eracks. & \begin{tabular}{|c|} 
Bad $\perp$ and slight $\|$ \\
crackss.
\end{tabular} & $\begin{array}{l}\text { G ood. } \\
\text { bonded. }\end{array}$ \% not & $\perp$ and $\|$ cracks & $\perp$ and $\|$ cracks & slightly erack & Bad $\perp$ and $\|$ eracks. & Bad $\perp$ and $\|$ eracks... & Slightly cracked.. & $\begin{array}{l}\text { Bad } \perp \text { and slight II } \\
\text { cracks. }\end{array}$ & Moderately cracke & $\begin{array}{l}\text { High shrinkage. No } \\
\text { adherence. }\end{array}$ & $\begin{array}{l}\text { Moderate shrinkage. } \\
\text { No adherence. }\end{array}$ & $\begin{array}{l}\text { High shrinkage. No adher- } \\
\text { ence. }\end{array}$ & $\begin{array}{c}\text { High shrinkage. No adher- } \\
\text { ence. }\end{array}$ \\
\hline$H-1$ & .....do. & Bad $\perp$ and $\|$ eracks. & $\begin{array}{l}\text { Badly cracked. } 10 \% \\
\text { not bonded. }\end{array}$ & do... & ........ & Badly cracked. & Glassy. Bulged.. & Glassy. Bulged. & $\begin{array}{c}\text { Badly cracked. } \quad 15 \% \\
\text { not bonded. }\end{array}$ & Glassy. Bulged.. & $\begin{array}{l}\text { Badly cracked. } \\
\text { not bonded. }\end{array}$ & $\begin{array}{l}\text { High shrinkage. No } \\
\text { adheronce. }\end{array}$ & $\begin{array}{c}\text { High shrinkage. No } \\
\text { adherence. }\end{array}$ & do do & 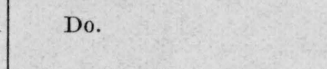 \\
\hline${ }^{I-1}$ & Good... & Good... & Very good... & Good... & Good... & Good. & $\perp$ and $\|$ cracks. & Bad $\perp$ and $\|$ eracks. & slightly cracked.... & Slightly glassy. & Moderately cracked... & Good. No adherence. & $\begin{array}{l}\text { Moderate shrinkage. } \\
\text { No adherence. }\end{array}$ & $\begin{array}{l}\text { Moderate shrinkage. No } \\
\text { adherence. }\end{array}$ & $\begin{array}{l}\text { High shrinkage. No adher- } \\
\text { ence. }\end{array}$ \\
\hline$L-1$ & .......... & ........ & ..._do... & ....do... & ....do... & Very good. & Good... & Good. & Vero & Good. & Very $\mathrm{g}$ & d...do. & Good. & Good. & Good. \\
\hline${ }^{M-1}$ & ........ & ......... & ......... & . do... & ...do... & ........ & $\mid \begin{array}{l}\text { Moderate } \\
\text { cracks. }\end{array}$ and $\|$ & $\perp \perp$ and $\|$ erack & slightly eracke & \begin{tabular}{|l} 
Moderate $\perp$ eracks. \\
SSlightly glassy.
\end{tabular} & slightly erac & . do & d & Moderate shrinkage. & Moderate shrinkage. \\
\hline $0-2$ & $\begin{array}{c}\text { Moderate } \perp \text { and } \| \\
\text { cracks. }\end{array}$ & Bad $\perp$ and $\|$ cracks... & $\begin{array}{l}\text { Moderately cracked. } \\
25 \% \text { not bonded. }\end{array}$ & $\underset{\substack{\text { Bad } \perp \text { and } \| \\
\text { eracks. }}}{\|}$ & Bad $\perp$ and $\|$ cracks. & $\begin{array}{c}\text { Badly cracked. } 50 \% \\
\text { not bonded. }\end{array}$ & Bad $\perp$ and $\|$ eracks. & Bad $\perp$ and $\|$ cracks & $\begin{array}{l}\text { Badly cracked. } 50 \% \\
\text { not bonded. }\end{array}$ & $\perp$ and || rackeks & Badly cracked & Badly cracke & $\begin{array}{l}\text { Badly cracked. No } \\
\text { adherence. }\end{array}$ & $\begin{array}{c}\text { Badly cracked. Bloated on } \\
\text { surface. High shrinkage. }\end{array}$ & Badly cracked and fused. \\
\hline${ }^{R-2}$ & Bad $\perp$ and $\|$ eracks... & $\begin{array}{c}\text { Moderate } \perp \text { and } \\
\text { cracks. }\end{array}$ & $\begin{array}{l}\text { Cracked and warped. } \\
35 \% \text { not bonded. }\end{array}$ & .....do.. & $\begin{array}{c}\text { Moderate } \perp \text { and } \| \\
\text { cracks. }\end{array}$ & $\begin{array}{l}\text { Cracked and warped. } \\
65 \% \text { not bonded. }\end{array}$ & $\perp$ and $\|$ cracks. & $\begin{array}{c}\text { Moderate } \perp \text { and \|| } \\
\text { cracks. }\end{array}$ & $\begin{array}{l}50 \% \text { curled and not } \\
\text { bonded. }\end{array}$ & $\begin{array}{c}\text { Moderate } \perp \text { and } \| \\
\text { crackss. }\end{array}$ & $\begin{array}{l}\text { Badly cracked. } 25 \% \\
\text { not bonded. }\end{array}$ & $\begin{array}{l}\text { Moderate shrinkage. } \\
\text { No adherence. }\end{array}$ & $\begin{array}{l}\text { Moderate shrinkage. } \\
\text { No adherence. }\end{array}$ & $\begin{array}{l}\text { High shrinkage. No adher- } \\
\text { ence. }\end{array}$ & $\begin{array}{l}\text { High shrinkage. No adher- } \\
\text { ence. }\end{array}$ \\
\hline \begin{tabular}{c|}
$w-1$ \\
$x-1$
\end{tabular} & $\perp$ cracks. & \begin{tabular}{|c|} 
do \\
Moderate $\perp$ cracks.
\end{tabular} & $\begin{array}{l}\text { Badly cracked. } 50 \% \\
\text { not bonded. } \\
\text { Good... }\end{array}$ & $\perp$ and $\|$ eracks & $\begin{array}{l}\text { Bad } \perp \text { and } \| \text { cracks. } \\
\text { Moderate } \perp \text { and } \|\end{array}$ & $\begin{array}{l}\text { Moderately crecked. } \\
30 \% \text { not bonded. } \\
\text { Good. }\end{array}$ & $\begin{array}{l}\text { Bad } \perp \text { and } \| \text { eracks. } \\
\perp \text { and } \| \text { eracks..... }\end{array}$ & $\perp$ and $\|$ eracks.... & $\begin{array}{l}\text { Badly cracked. } 30 \% \\
\text { not bonded. } \\
\text { Moderately cracked... }\end{array}$ & $\begin{array}{l}\text { Bad } \perp \text { cracks } \\
\text { Bad } \perp \text { and } \| \text { cracks. }\end{array}$ & $\begin{array}{l}\text { Baaly cracked. } 25 \% \\
\text { not bonded. } \\
\text { Badly cracked. }\end{array}$ & $\begin{array}{l}\text { No adherence. High } \\
\text { shrinkage. } \\
\text { Good_. }\end{array}$ & $\begin{array}{l}\text { Cracked. No adher- } \\
\text { ence. } \\
\text { Slightly cracked... }\end{array}$ & $\begin{array}{l}\text { High shrinkage. No adher- } \\
\text { ence. } \\
\text { High shrinkage... }\end{array}$ & $\begin{array}{l}\text { High shrinkage. No adher- } \\
\text { ence. } \\
\text { High shrinkage. Glassy. }\end{array}$ \\
\hline$Y-1$ & ...do.. & $\perp$ cracks...... & $\begin{array}{l}\text { Moderately cracked. } \\
50 \% \text { not bonded. }\end{array}$ & & Bad $\perp$ cracks. & $\begin{array}{l}\text { Badly cracked and } \\
\text { and warped. } \\
\text { and }\end{array}$ & || eracks.. & Bad $\perp$ cracks. & $\perp \underset{\text { cracks. }}{\text { and }} \|$ thermal & & & & & & \\
\hline
\end{tabular}

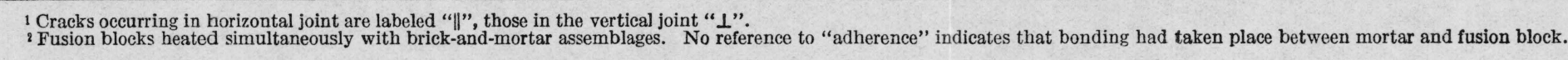


After heating the piers at $1,500^{\circ} \mathrm{C}$, the mortars having low pyrometric-cone equivalents $(E-2, F-1, F-2, G-1$, and $X-1)$ indicated their lack of refractoriness by becoming glassy. In addition, several mortars $(I-1, M-1, O-2)$ of highest refractoriness also showed signs of fusion, apparently because of the migration of salts to the surface.

As stated in section IV-e, the conclusions drawn from the appearance of the mortar after heating in the fusion blocks (table 4) correlate well with those drawn from an examination of the piers; that is, much pertinent information relative to the quality of the mortar may be obtained from the former test.

\section{SUMMARY AND CONCLUSIONS}

Seventeen air-setting refractory mortars (four of which had a chromite base) marketed in the dry condition and furnished by 12 manufacturers were subjected to a series of tests. Different amounts of water were added to the mortars to obtain consistencies suitable for preparing specimens of the neat mortar and for use in bonding brick by troweling and dipping methods.

Six of the mortars were furnished in metal drums and the remainder in paper-lined jute sacks. They remained in storage from 1 week to 49 months before being tested.

The water required for bringing the mortars to a troweling consistency ranged from 16.6 to 43 percent, and that required for a dipping consistency ranged from 20.7 to 60.1 percent. The ease of troweling on brick, determined mechanically, was considered satisfactory for all but five of the mortars. The workability of seven of the mortars was considered unsatisfactory when of a dipping consistency. The percentage flow (consistency), as determined with a flow table, ranged from 24 to 110 , with 12 of the mortars ranging between 62 and 86 . After slaking in water 1 hour, 16 of the 17 mortars showed less than 4 percent retained on a No. 40 United States Standard Sieve, and in no case was the residue on a No. 20 sieve greater than 0.5 percent. The free-alkali content, expressed as sodium oxide, ranged from 0 to 1.90 percent. The pyrometric-cone equivalents of the mortars ranged from 20 to above 38 , with very little difference between the end points of calcined and uncalcined materials. Eight of the mortars, mechanically troweled on brick and dried, cracked seriously. The time required for the mortars to airset (indication of water retention), indicated by their resistance to flow under load, ranged from 1 to 30 minutes when used to bond firebrick of 8.6-percent absorption.

The average transverse dry strengths of the air-set neat mortars ranged from 250 to $4,990 \mathrm{lb} / \mathrm{in}^{2}$. With three exceptions, the strength of the test specimens was considerably greater when the surface uppermost during drying was in tension in the breaking test. Eleven of the mortars showed lower strengths after heating at $750^{\circ} \mathrm{C}$ than after heating at $1,000^{\circ}$ or $1,350^{\circ} \mathrm{C}$. four being weakest after airdrying and two strongest.

The bonding strength of the dried mortars in assemblages of two half-brick and mortar ranged from 45 to $480 \mathrm{lb} / \mathrm{in}^{2}$.

Brick specimens bonded with 11 of the 17 mortars were weaker after heating at $1,000^{\circ} \mathrm{C}$ than after drying or heating at $750^{\circ} \mathrm{C}$. Furthermore, seven of the mortars preheated at $1,000^{\circ} \mathrm{C}$ had prac-

446682-42-2 


\section{Journal of Research of the National Bureau of Standards}

tically no bonding strength. In these tests, failure of the assembly occurred either in the brick, in the mortar, in the joint, or in some combination of these.

Piers of two standard-size brick and two half-brick (making two horizontal and one vertical joint) were made up with 1/8-in. and 1/16-in. joints. The mortar joints of piers for five of these mortars, all of which had high drying shrinkages, were badly cracked after drying. Also, as a result of the heating at $1,500^{\circ} \mathrm{C}$, eight of the mortars had either become fluid enough to bulge from the joints or had cracked.

Some of the mortars shipped and stored in sacks, rather than in airtight containers, would undoubtedly have had better strength and bonding properties if they had been tested soon after manufacture.

The mechanical-troweling test is a much better measure of the workability of a mortar than is the water-retention or time-of-set test.

The failure of a cap of mortar to adhere to brick was no indication of its bonding properties.

Much pertinent information relative to the quality of a mortar may be obtained from the fusion-block test.

The technical requirements in a Federal specification for this commodity will be based on the results of tests made in this investigation. The requirements for such a specification will probably cover fineness, bonding strength, refractoriness, and workability. If the limits for these properties are so chosen as to insure a product of the proper quality, then from the results of this investigation it may be concluded that because so few will fall within those limits, airsetting mortars of the dry type as a class may possibly be greatly improved.

Washington, January 16, 1942. 